\title{
PROJEKTTERVEZÉS: MÚLT, JELEN ÉS JÖVŐ
}

A szerzố a projekttervezés történetének ötvenéves évfordulója, s talán mondhatjuk, hogy a projektmenedzsment-tudomány/szakma születésének ötvenéves évfordulója alkalmából visszatekint a kezdetekre. A projektek tervezésének fejlódési folyamatait elemezve megkísérli a tapasztalható trendek figyelembevételével a jövố fejlódési irányait megbecsülni.

\section{Kulcsszavak: projekt, projekttervezés, hálós tervezési technikák, projektmenedzsment}

A projekttervezés „tudománya” 2007-ben ünnepelte születésének 50. évfordulóját. 1957-ben került sor az elsố matematikailag is megalapozott projekttervezési eljárás, a ma CPM (Critical Path Method) néven ismert technika gyakorlati kipróbálására. A technika nem a semmiból keletkezett, a projektek tervezésének ekkor már több különböző technikája is ismert volt, s a CPM fejlesztésével szinte egy idôben több helyen is folytak olyan kutató-fejlesztő munkák, melyek más eljárások kifejlesztéséhez is vezettek. Ennek ellenére kétségtelenül ez volt az az eljárás, melynek születésével a projektmenedzsment mint saját „eszköztárral” rendelkezó alkalmazott tudományág polgárjogot nyert a tudományos és a gazdasági életben is.

Gyakorlatilag a projekttervezési technikák (CPM) kifejlesztésétôl datálódik a projektekkel foglalkozó szakértók szakmai közösségekbe való tömörülése, azaz a projektmenedzsment szakmai szervezetek (PMI) megalakulása is.

A projektmenedzsment kifejezés értelmezése ma már lényegesen szélesebb körú, mint ötven évvel ezelőtt. Ma számos olyan területe van a projektmenedzsmentnek, melyekkel az 50-es években még nem foglalkoztak. Ennek a bővülésnek köszönhetően létrejött a projektmenedzsment területén belül is a specializáció, mely már nem követeli meg a projektmenedzsertól a mély és átfogó projekttervezési és kontrollingismereteket. Ezeket a tevékenységeket nagyobb projektek esetén már önálló feladatkörrel rendelkezó projekttervezók, illetve kontrollerek végzik, s ezen tevékenységhez szükséges speciális szaktudás miatt a projekttervezést és kontrollingot mára önálló szakmának tekinthetjük.

\section{Az ,őskor”}

A tervezés/ütemezés szükségességének felismerése gyakorlatilag egyidôs az emberiséggel, írásos dokumentumai pedig már az írásbeliség kezdetétól megtalálhatók.

A piramisok, a kínai Nagy Fal s a világ nagy építési munkái nem épülhettek volna fel valamilyen formájú ütemezés nélkül. Noha jelenlegi ismereteink szerint írásos nyoma nem maradt fenn a piramisok tervezésének, szervezésének, arról bizonyítékaink vannak, hogy a piramisok építésénél védték a munkások szemét az erốs naptól, és ,üzemorvos” is dolgozott a projekt helyszínén (Smith - Hawass, 2006). Sun Tzu (ie. 544-496) kínai hadvezér a „Háború múvészete” c. könyvében már írt az ütemezés fontosságáról, a csaták előre történő tervezésének, modellezésének kérdéseiről.

Az amerikai kontinenst átszelô vasútvonalak (186269) építésénél használt írásos technikák a mai eszköztárban mérföldkő́tervként ismert tervezési formák megfelelői voltak. (A nyomvonalterv mellett tüntették fel az adott helyszín tervezett elérésének dátumát.) Az építésnél rendkívüli problémát okozott a talpfák, illetve a sínek nagy távolságból való biztosítása, ennek ellenére Grenville Dodge, a kivitelezést (Union Pacific Railroad) irányító fômérnök a következôket írta viszszaemlékezéseiben: „Nem emlékszem egyetlen olyan esetre sem a vonal építése során, amikor az építkezés akárcsak egy hetet csúszott volna a szükséges eróforrások (értsd építésnél felhasznált anyagok) hiánya miatt" (1. ábra). 
A transzkontinentális vasútvonal építése

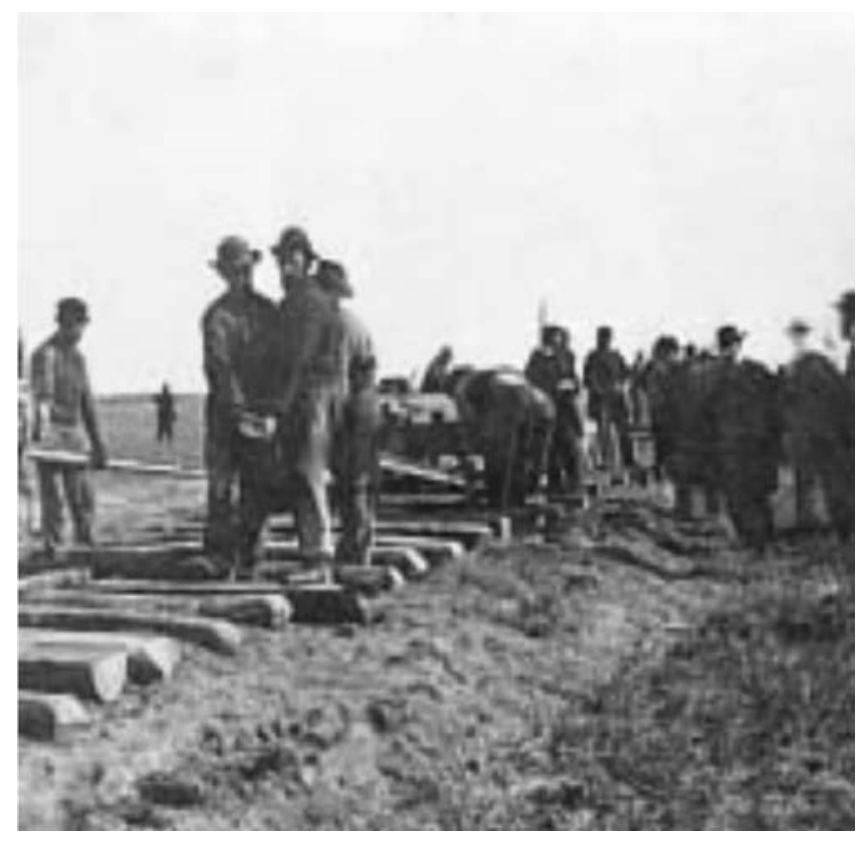

Magyarországon az 1300-as évek végéról Luxemburgi Zsigmond magyar király és német-római császár korából származnak írásos feljegyzések, melyek a pozsonyi, illetve a visegrádi várak bóvítési munkáinak ütemezéséról, költségtervezéséról, sốt az építés kontrolljáról is tanúskodnak. „Az építést vezető Péter, királyi architector jelentős összeget, 200 aranyforintot kapott fizetésül 1420-ban múvészi képességeinek elismeréseként csakúgy, mint technikai jártasságáért" - olvashatjuk Mályusz Elemér könyvében a budai királyi palota továbbépítéséról szóló részleteknél (Mályusz, 1984). A példákat oldalakon keresztül sorolhatnánk, de talán ezek is rávilágítanak a projekttervezés „őskorának" legfontosabb jellemzójére, melyet úgy foglalhatunk öszsze, hogy az igény az időbeli és a költségtervezésre egyre fokozódó mértékben megjelent, formalizált tervezési technikák azonban nem léteztek. A tervezési eszközök az 1900 évek elején kezdôdtek formalizált alakot ölteni, azonban ez már a projekttervezés történetének újabb időszakát jelentette.

\section{A ,középkor”}

A menedzsmenttudomány Henry L. Gantt amerikai mérnököt tartja a sávos ütemterv kifejlesztőjének (1917), melyet róla Gantt-diagramnak is neveznek (Gantt, 1903, Gantt, 1919). A Gantt-diagram egy olyan grafikus ütemterv, mely a tevékenységek tervezett lefolyását idôskála mentén mutatja be. Sávos ütemtervet mutat a 2 . ábra ${ }^{l}$. A sávos ütemterv mint tervezési eszköz rendkívül statikus, mely alatt azt értjük, hogy az ütemterv módosítása nehéz és idôigényes folyamat. Ennek oka az, hogy ez a tervezési technika nem őrzi meg az ốt létrehozó logikát (az a tervező agyában vagy jegyzeteiben marad), csak visszatükrözi, és annak eredményét egyszerú, érthetô grafikus formában elérhetővé teszi. Az ilyen eszközöket ma a projektmenedzsment tradicionális tervezési technikáknak hívja (2. ábra).

Ezzel egy időben jött létre a mérföldkődiagram, melyet fóleg olyan projektek esetében alkalmaztak, amikor a célok megvalósulásához szükséges lépések nem voltak ismertek, vagy nem voltak lényegesek a tervező, illetve a szerződő felek számára, de a cél eléréséhez

\section{2. ábra}

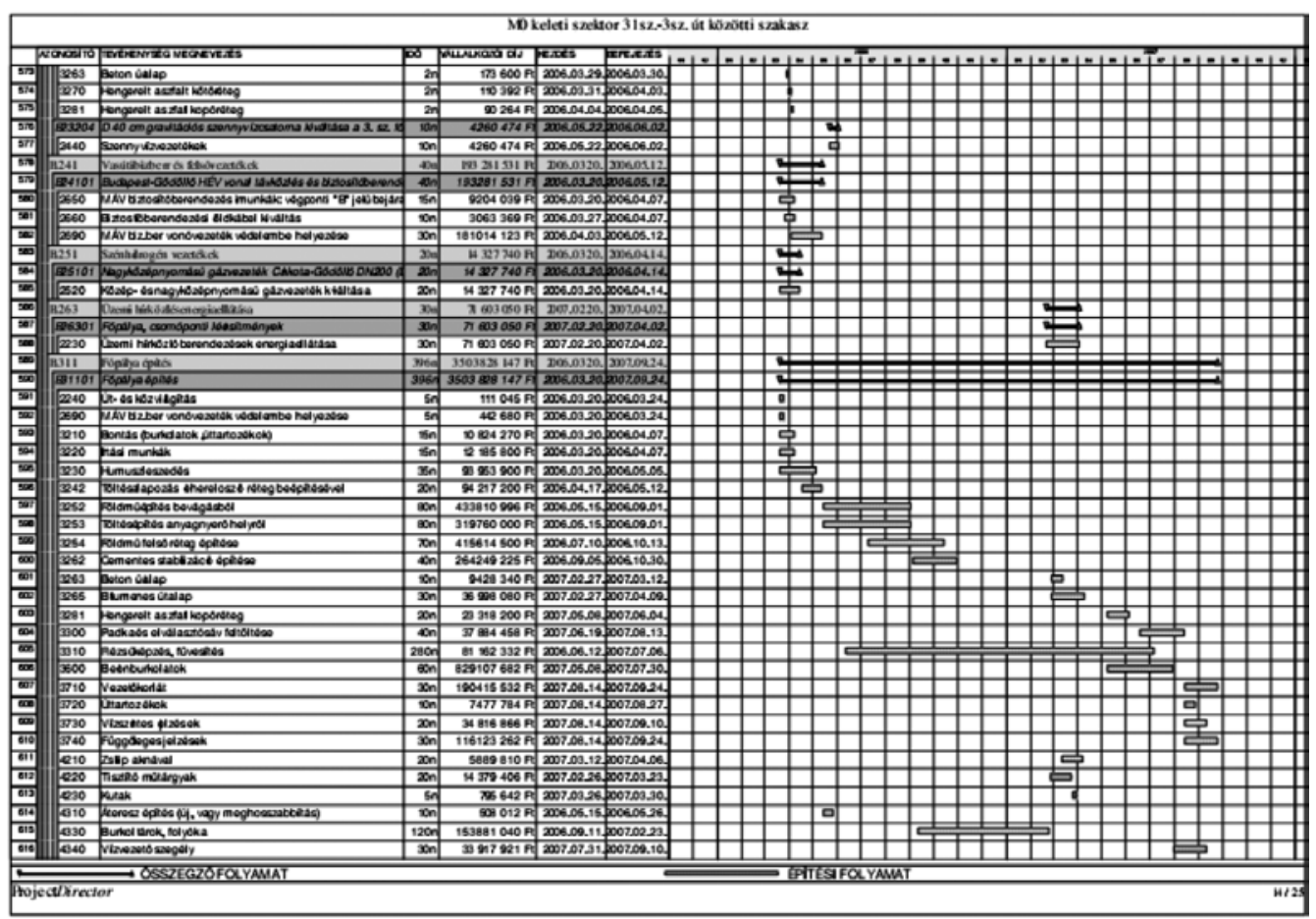


3. ábra Tudománytechnikai kuriózumnak

\section{Ciklogram}

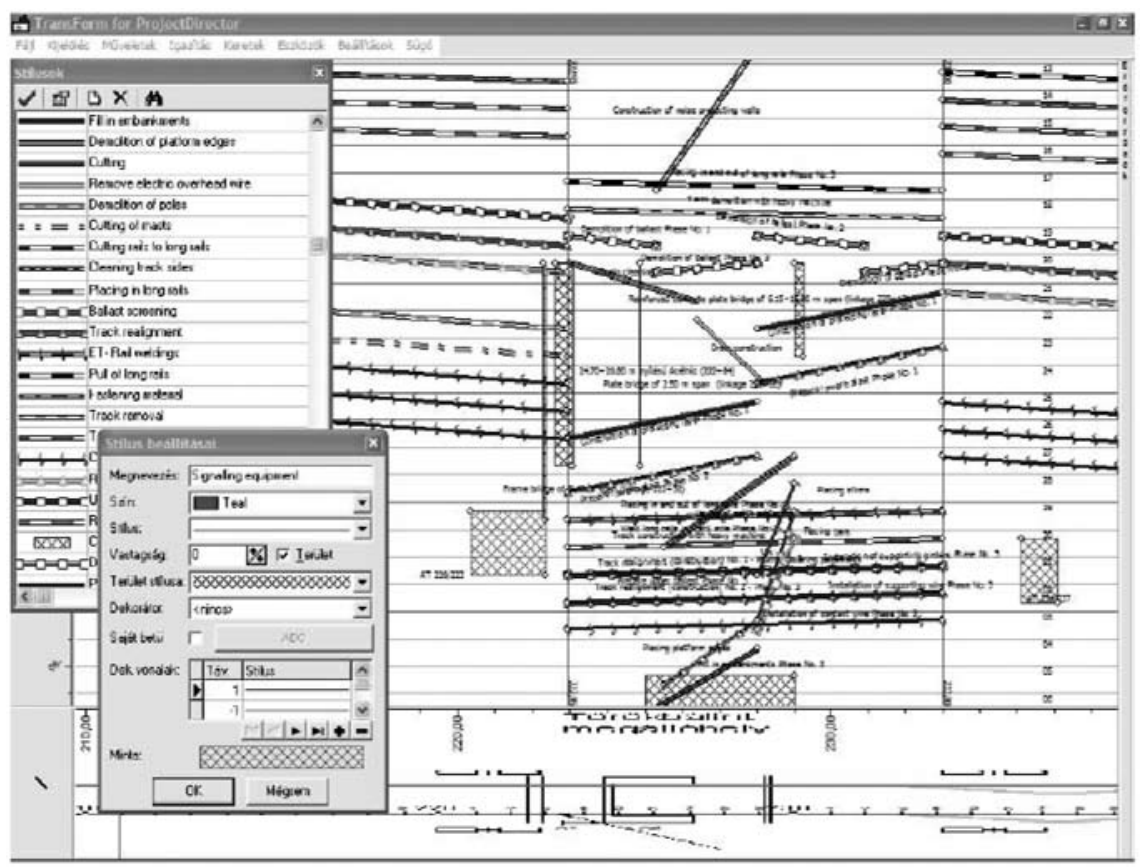

tekinthető Georgi Grechko,szovjet kozmonauta által kézzel készített úrutazásokra adaptált ciklogramja, melyen a Szaljut-6 ứállomáson (1977. dec. 10. - 1978. márc. 16.) tett 96 napos tartózkodásának 150 napfelkeltéjét, az úrsétákat és a tisztálkodások idôpontjait is feltüntette (4. ábra). Ez azt is bizonyítja, hogy a ciklogram, illetve a sávos ütemterv mind a mai napig használatban levố eszköz a tervezés területén is (4. ábra).

A projektek tervezését a $\mathrm{XX}$. sz. fordulójától kezdve szinte kizárólag az ún. tradicionális technikák uralták, melyekról összegzésképpen elmondhatók, hogy egyszerú, jól áttekinthetô információt szolgáltattak a tervezett megvalósulásról, azonban a terve- szükséges fốbb állomásokat idôben rögzíteni akarták. Ennek a tervnek a grafikus megjelenése rendkívül hasonlít a sávos ütemtervre, a vízszintes tengelyen az idő, a függóleges tengelyen a projekt tevékenységei (Ganttütemterv) helyett a projekt fontosabb mérföldkövei lettek felsorolva. Kutatóhoz vagy alkalmazóhoz kötődố elsốbbség itt nem állapítható meg, a menedzsment folklór részeként tekintünk a technikára.

A tradicionális tervezési technikák egy régebben ismert, bár mára szinte elfeledett tervezési technikája a Line of Balance eljárás (LOB), melyet a Goodyear vállalatnál kezdtek fejleszteni a 30-as évek végén, a 40-es évek elején, George Fouch (1941) vezetésével, ismétlődő folyamatok tervezésére. Alkalmazása is a gyáriparban érte el a legmagasabb fokát (Bonnal, 2005).

Grafikus megjelenésében a LOB-technikához, elveiben a Gantt-diagramhoz hasonló eljárás a ciklogram angolul Linear Scheduling Method -, melyet a 3. ábra ${ }^{2}$ mutat. A ciklogram az ütemterv tevékenységeinek nemcsak az időbeli lefolyását mutatja, hanem a térbelit is. Egyik tengelye az idô, a másik a térbeli elhelyezkedésre utaló adat (pl. autópályáknál a szelvényszám), míg a tevékenységek a grafikonon jelennek meg önálló szakaszonként. A technika felmérhetetlen elônye, hogy a tevékenységek térbeli elhelyezkedéséról is grafikus információt ad, de a kétdimenziós ábrázolásnak köszönhetốen használata korlátozva van az ún. vonalas létesítményekre, ahol a projekt térbeli elhelyezkedése egydimenziósnak tekinthetô (3. ábra).
4. ábra
A Szaljut-6 úrállomáson való tartózkodás ciklogramos ütemtervrészlete

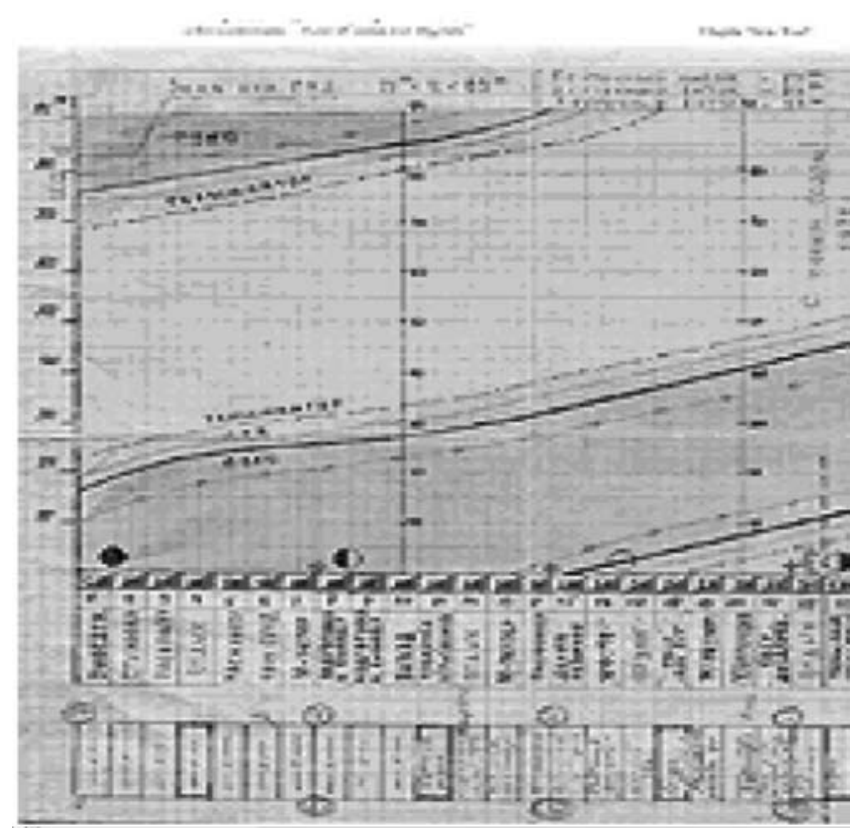

zés és a módosítás rendkívül nehézkes volt, mert a terv nem órizte meg az ôt létrehozó technikát. A fenti okok miatt fordult a kutatás olyan irányba, mely a projekt belsố összefüggéseit tárolni képes, így a módosítást egyszerúvé tevő technikák a hálós tervezési technikák kifejlesztéséhez vezetett. 


\section{Az ,újkor”}

A projekttervezési eszközök korszerú, a projekt belsố összefüggéseit tárolni képes eszközök fejlesztése a XX. század 30-as éveiben kezdődött, amikor Karol Adamiecki 1931-ben publikálta a harmonygráf eljárást (Adamiecki, 1931), mellyel egyébként már 1896-ban kezdett foglalkozni. Ez az eljárás a mai hálós technikák előfutárának tekinthetô (5. ábra).

A módszer megórizte a rendszer összefüggéseit, azaz a logikai kapcsolatokat, és gyakorlatilag olyan hálós eszköznek volt tekinthetô, melyen a projekt átfutási ideje, $\mathrm{s}$ a tevékenységek korai kezdete és befejezése kalkulálható volt. (Csak a legkorábbi idópontok!)

Ez a munka, valamint a gráfelmélet és az operációkutatás második világhábo-

\section{Az UNIVAC 1 a Du Pont konszernnél}

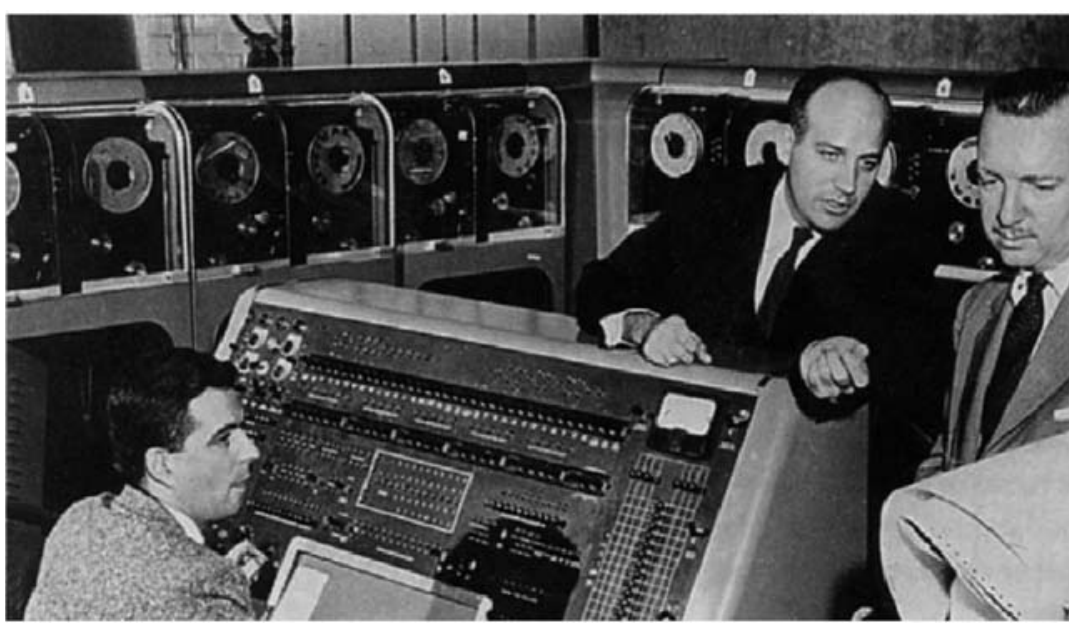

6. ábra
Az Adamiecki által kifejlesztett harmonygráf

\begin{tabular}{|c|c|c|c|c|c|c|c|}
\hline & \multirow{2}{*}{ Trom } & - & \multirow{2}{*}{-2} & \multirow{2}{*}{-} & \multicolumn{2}{|c|}{\begin{tabular}{c|c|}
$A-1$ & $B-1$ \\
\end{tabular}} & \multirow{2}{*}{$\cdots$} \\
\hline & & & & & \multirow{2}{*}{$\frac{A-3}{A-2<C}$} & \multirow{2}{*}{ 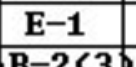 } & \\
\hline time & activity & $A-1<4)$ & $B-1<4)$ & $\mathrm{D}-1(2)$ & & & \\
\hline \multicolumn{8}{|c|}{\begin{tabular}{|l|l|l|l|l|l|l|l|l|}
1 & \\
\end{tabular}} \\
\hline \multicolumn{8}{|c|}{2} \\
\hline \multicolumn{8}{|c|}{$\mathbf{3}$} \\
\hline \multicolumn{8}{|c|}{4} \\
\hline \multicolumn{8}{|c|}{5} \\
\hline \multicolumn{8}{|c|}{6} \\
\hline \multicolumn{8}{|c|}{7} \\
\hline \multicolumn{8}{|c|}{8} \\
\hline \multicolumn{8}{|c|}{9} \\
\hline \multicolumn{8}{|c|}{10} \\
\hline \multicolumn{8}{|c|}{11} \\
\hline \multicolumn{8}{|r|}{ 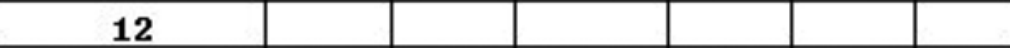 } \\
\hline \multirow{2}{*}{\multicolumn{2}{|c|}{$\begin{array}{r}13 \\
14\end{array}$}} & & & & & & \\
\hline & & & & & & & \\
\hline
\end{tabular}

UNIVAC számítógép a világon és az elsô a gazdasági szférában) elhatározta, hogy az eddig folyó elméleti kutatásait, melyeket az éves karbantartási folyamatok optimalizálása érdekében végeztek, számítógép segítségével teszi eredményesebbé (6. ábra).

A Du Pont menedzsmentje úgy gondolta, hogy a tervezés, a költségek optimalizálása kiváló lehetôség a számítógép használhatóságának bizonyítására. A Du Pont saját mérnökét, Morgan Walkert bízta meg azzal a munkával, hogy „,derítse" ki, vajon az UNIVAC használható-e ilyen jellegú feladatok megoldása során. A Du Ponton belül más kutatók is foglalkoztak a probléma vizsgálatával, de gyakorlati szempontból használható rú alatt történő keletkezése és fejlődése vezetett a mai gyakorlatban túlnyomórészt használt korszerú tervezési technikák, a hálós tervezési technikák kifejlôdéséhez. A projekttervezés történetének harmadik korszakát az elsố hálós tervezési eljárás, a CPM-technika kifejlesztéséhez lehet kötni, s mint már említettük a bevezetốben, innen datálódik a projektmenedzsment mint önálló tudományterület és önálló eszköztárral rendelkező szakma elismerése is.

A CPM-technika kifejlesztésének kezdete 1956ra datálódik, amikor az E. I. du Pont de Numours (Du Pont) a tulajdonában levô UNIVAC1 számítógép jobb kihasználása érdekében (ez volt a harmadik legyártott megoldással egyiküknek sem sikerült előállni.

1956 második fele és 1957 eleje között Morgan Walker és az idóközben a kutatásban hozzá csatlakozó James E. Kelley a Remington Rand kutatóintézettól, definiáltak egy létezô projektet, melynek felderítették a belsô összefüggéseit.

A projekten az alábbi feladatot fogalmazták meg: Adottak egy projektben tevékenységek, melyeket normál tempóban normál költségért, rohamtempóban, végezni. Észrevették, hogy egyes tevékenységek gyorsítása nem gyorsítja a projektet, csak a költséget növeli, más tevékenységek gyorsítása viszont amellett, hogy a költséget növeli, a projekt megvalósítási idejét is csökpedig egy ennél nagyobb ún. rohamköltségért lehet el- 
kenti. A cél ezek után nyilvánvaló volt, megtalálni azokat a tevékenységeket, melyek idejének csökkentésével a projekt költsége minimálisan nô.

1957. május 7-én a Du Pont és a Remington Rand 226.400 dollár értékben hivatalosan is létrehozta a CPM-projektet, melyben a Du Pont része 167.700, a Remington Rand része 58.700 dollár volt. A Du Pont részérôl a kutatást Morgan Walker vezette, aki a problémát megfogalmazta, s a Remington Rand kutatórészleg-vezetóje James E. Kelly volt, a matematikus, akire a probléma matematikai megoldása hárult. Kelly a feladatot egy paraméteres lineáris programozási feladatra vezette vissza, s ezzel lehetővé tette a feladat megoldását.

A probléma kezelhetőségét az is hátráltatta, hogy a háló grafikus ábrázolása nem létezett, azt egy mátrixban írták le, ahol a sorok és az oszlopok jelentették az eseményeket és a mátrix cellái pedig az eseményeket összekötố tevékenységeket. A grafikus ábrázolást, a tevékenységélú (Activity-on-Arrow) ábrázolást is e kutatási projekt keretében fejlesztették ki.

1957. július 24-ére a kutatócsoport egyik tagja, George Fischer sikeresen futtatta a feladatot, és a számítógépen megtörtént az elsô CPM-probléma megoldása. A háló 61 tevékenységet és 16 látszattevékenységet

\section{Az elsố számítógépes CPM-elemzés eredménye}

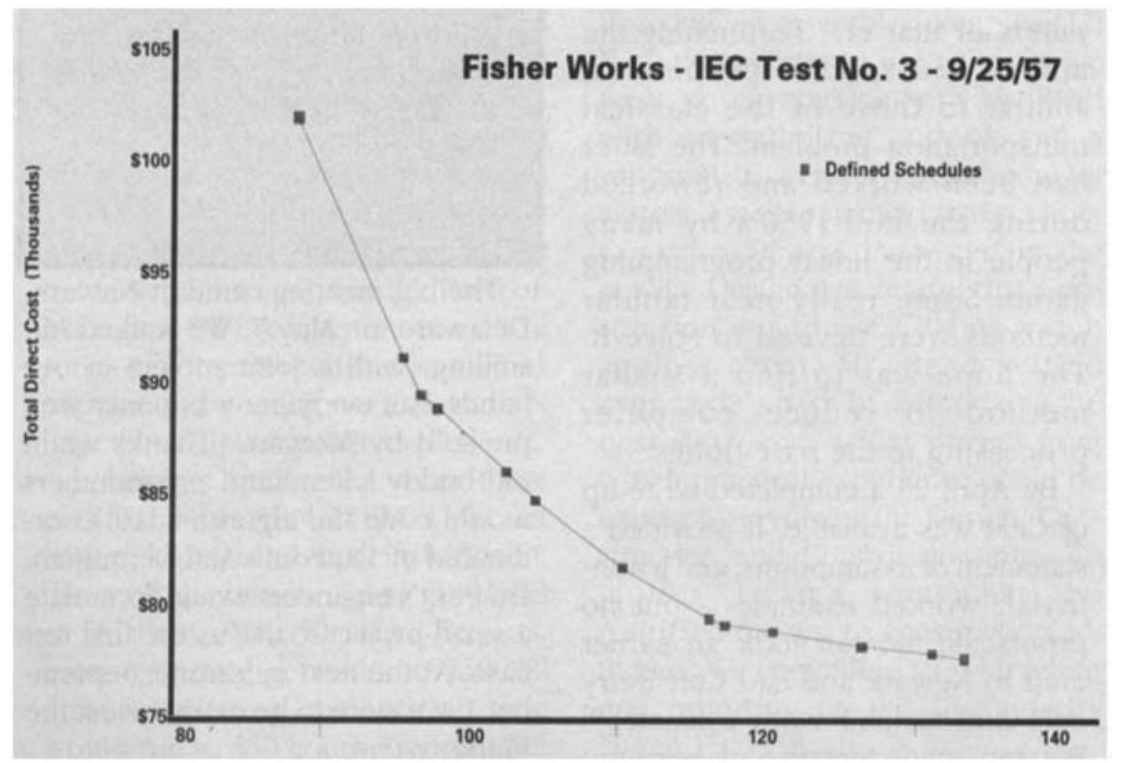

ütemterv esetén 350 gépóránál sosem lett gyorsabb, s az olyan ütemezési hibák, mint egy hurok felderítése és kiküszöbölése egy jobb autó árába került.

A CPM-technikát 1959-ben egy konferenciakiadványban hozták a tudományos közélet számára nyilvánosságra (Kelly - Walker, 1959), majd teljes pontossággal egy operációkutatással foglalkozó lapban is megjelent 1961-ben (Kelly - Walker, 1961), de ekkor már az 59-es publikációnak köszönhetốen kutatók és mérnökök hada foglalkozott a CPM-módszerrel.

A CPM-technika fejlődése két irányban indult tovább. Matematikusok egyre szebb és elegánsabb megoldást adtak a feladatra, pl. hálózati folyam modellt (Ray Fulkerson, 1961), vagy dinamikus programozási technikát (Hindelang - Muth, 1979) használva.

Az eredeti algoritmus feltételezte, hogy a költséggörbe változása egy adott tevékenység esetén a rohamés a normál költség között lineáris, ezt a megkötést oldotta fel az a továbbfejlesztés, mely lehetôvé tette a költséggörbében diszkrét pontok alkalmazását (Meyer - Shaffer, 1963).

Magyar vonatkozás a CPM-feladat megoldására kifejlesztett, véleményem szerint legegyszerúbb algoritmus (Klafszky Emil, 1969), illetve a feladat adott 7. ábra átfutási idôhöz tartozó legnagyobb költségú megoldásának megkeresésére kifejlesztett algoritmus (Crandall Hajdu, 1997). A CPM-feladat érdekes továbbfejlesztése, a legkisebb költségú megoldás megkeresése abban az esetben, ha a késésért kötbért kell fizetni (Elmegrabhy, 1964). A feladat megoldására számítógép használatát nem igénylő, egyszerú, gyors, ámde heurisztikus megoldást fejlesztett ki John Fondahl, aki a legtöbbet tette a CPM-technika népszerúsítéséért az építóiparban (Fondahl, 1961).

A CPM-technika másik fejlődési iránya az alkalmazásból indult ki. Az alkalmazó mérnökök úgy találták, hogy a technika alkalmazhatatlan egyrészt a számítógépek hiánya és a drága gépüzemórák miatt, másrészt amiatt, hogy a tevékenységek költtartalmazott. Az elemzés végeredményét, azaz az adott átfutási idókhöz tartozó legkisebb költségú megoldást mutatja a 7. ábra, míg a 8. ábra az ütemtervet, illetve az algoritmus múködését magyarázó rajzot tartalmazza.

Az algoritmussal, illetve a technikával rendkívül sok probléma volt: a futtatás elókészítése, és maga a futtatás az átlagosan 150-300 tevékenységet tartalmazó séggörbéinek meghatározása rendkívül időigényes, és idônként szakmailag és kivitelezhetetlen feladat. További ellenérzést és idegenkedést okozott a lineáris programozási technika nehézsége, mely csak a matematikusok kis csoportja számára volt érthetô.

A fentiek miatt elindult a technikának egy olyan egyszerúsítése, mely oda vezetett, hogy a 60-as évek végére 
az eredeti CPM-feladat helyett egy olyan lecsupaszított feladatot hívtak CPM-feladatnak, ahol a tevékenységnek csak normál ideje volt, azaz az elemzés egy szimpla időelemzéssé (matematikai értelemben leghosszabb/legrövidebb út keresésére) korlátozódott.

A PERT-technika kifejlesztése 1957-ben kezdôdött a Polaris rakétaprogram indításakor. Az Amerikai Haditengerészet Kiemelt Projektek Irodája (Special Project Office) azt a feladatot kapta, hogy találjon ki egy eljárást a programban részt vevő mintegy 9000 vállalkozó és alvállalkozó munkájának összehangolására (Polman, 1994; Weaver, 2006). A programot az SPO menedzselte, mely ismerte a Du Pont-nál folyó munkát, így pl. a hálós ábrázolás módszerét is, mely kiváló grafikus eszköznek bizonyult a projekt tevékenységeinek és összefüggéseinek megjelenítésére az addig használt mátrixos leírás helyett. Az SPO-t a munkában egy konzultáns cég, a BoozAllen és Hamilton, valamint a Lockheed repülőgyár rakétafejlesztô szervezete is segítette. A projekt a hidegháború ,terméke” volt. Az eredetileg 1965 végére tervezett projekt felgyorsítására vonatkozó lépések megtételére az elsô múhold, a Szputnyik 1957. október 4-i fellövését követő hisztérikus légkörben került sor. 1958-ban az SPO utasította a kutatócsapatot (Clark, Malcolm és J. H. Roseboom a Booz - Allen és Hamiltontól, valamint R. Young, E. Lennen a Lockheedtól) a „Performance Evaluation and Review Technique" eljárás kifejlesztésére. Az SPO részéről W. Fazar irányította a munkát. Munkájuk eredménye volt az a technika, melyet ma PERT-nek neveznek (Malcolm, 1959).

A PERT-technika a grafikus ábrázolásában a CPMtechnikával azonos volt, azonban eseményorientált volt a CPM-tevékenység orientáltsága helyett. Az eseményorientáltság (amikor nem a tevékenységek lefolyása, hanem az egyes mérföldkövek, fontosabb események bekövetkezte az érdekes) jobban megfelelt az amerikai haditengerészet jelentési rendszerének. A PERT-technika jelentôs különbsége, hogy a tevékenységidôket valószínúségi változóként kezelte, melyek bétaeloszlást követnek. Ebben a hálótechnikában a logikai öszszefüggéseken túl a tevékenységidók eloszlását leíró adatok voltak a bemeneti adatok, az elemzés eredménye pedig a projekt, illetve az egyes események adott időre történő bekövetkeztének valószínúsége volt. A kutatás nagy jelentôségú addicionális eredménye az a részletes metodológia volt, mely leírta a tervezés, ütemezés és kontroll lépéseit (pl. a WBS, azaz a munkalebontási szerkezet mint tevékenységdefiniálási módszer kifejlesztése is a PERT-projekthez köthetô).
Az MPM-technika kifejlesztése szintén az 1950-es évek végére datálódik, amikor egy francia kutató 1958ban (B. Roy) kifejlesztette a "Method of Potentials" módszert (Roy, 1959; 1962). A technika tevékenységcsomópontú ábrázolást követett (a gráf csomópontjai reprezentálták a tevékenységeket és az élei a logikai összefüggéseket). Roy módszere csak a kezdés-kezdés (Start-to-Start) összefüggést ismerte, de a modell tartalmazta a maximális kezdés-kezdés (max Start-toStart) kapcsolatot is, melyet a kereskedelemben elérhetô legismertebb angolszász eredetû projekttervezô szoftverek a mai napig nem alkalmaztak. (A szokásos - az ún. minimális - kapcsolatok a tevékenységek kitüntetett pontjai közötti minimális idôbeli távolságot írják elő, míg a maximális kapcsolatok a legnagyobb megengedett időtávot.)

Munkájára a német kutatók által 1966-ban kifejlesztett válasz a HMN-technika volt, mely a befejezés-befejezés és a maximális befejezés-befejezés kapcsolatot ismerte, majd az 1968-ban kifejlesztett VNP (Vorgangsknotennetzpläne), mely a befejezés-kezdés és a max befejezés-kezdés kapcsolatot ismerte. Ezzel gyakorlatilag egy idóben, egy IBM 1440-es géphez készített projekttervező rendszer készítésénél kifejleszték a PDM (Precedence Diagramming Methode) elnevezésú technikát (IBM, 1964), mely a minimális kapcsolatok közül négyet (kezdés-kezdés, befejezés-befejezés, befejezés-kezdés, kezdés-befejezés) ismert, de a maximális kapcsolatokat nem tudta kezelni. Az angolszász tudományos és szakmai világ Jim Craig nevéhez köti a PDM-technika kifejlesztését, de látható, hogy az MPM-technika születése nem olyan egyértelmú és határozott, mint a PERT- vagy a CPM-technikáé, és fooleg a francia és német, de a közép-európai országokban is MPM-technikának nevezzük azt a technikát, mely sok átalakulás után nyerte el mai formáját. Az MPMtechnika elónyei miatt ma a kereskedelemben kapható projekttervező rendszerek közül szinte mindegyik ezt a technikát implementálta.

Számtalan egyéb figyelemre méltó munka jelent meg a 60-as és 70-es években, melyek valamilyen módon a fent említett három technika valamilyen továbbfejlesztésén alapultak. Ezek közül néhány jelentősen továbbfejlesztette a technikákat. A legérdekesebb továbbfejlesztés a döntési csomópontok hozzáadása a technikához, mely lehetôvé tette az egy hálóban történő szimulációt. Ennek a munkának egyik úttöróje Freeman volt (Freeman, 1960), akinek munkáját Eisner (Eisner, 1962) és Elmagrabhy (Elmagrabhy, 1964; 1977) általánosította. (Munkájuk három új döntési csomópontot illesztett a technikába, AND, Exclusive-Or, Inclusive-Or). 
Munkájuk adta az alapot a GERT (Graphical Evaulation and Review Technique) eljárás kifejlesztéséhez (Alan Pritsker, 1966a; 1966b). A GERT hamar önálló kutatási iránnyá nőtte ki magát, pl. a négyféle logikai összefüggést tartalmazó Precedence-GERT (Pritsker, 1974). Arisawa és Elmagrabhy által 1972-ben kifejlesztett algoritmus a GERT-hálóban oldotta meg a költségoptimalizálási feladatot (Arisawa, 1972). Az MPM-hálón a költségoptimalizálási feladatot magyar kutatók oldották meg (Hajdu, 1993; 1997; Mályusz, 2004).

A felsorolás közel sem teljes. Jelenleg mintegy száz hálós tervezési eljárást, és annak mintegy ezer változatát ismeri a tudomány. A mai napig születnek új technikák, de széles körú szakmai elfogadottságot csak kevés ér el. Ma a projekttervezési gyakorlatban az MPM-technika a domináns, a kereskedelmi forgalomban kapható szoftverek túlnyomó része az MPM-technika alkalmazásán alapszik. (A továbbiakban MPM-technikán azt a hálótervezési eljárást értjük, mely a tevékenységekról felteszi, hogy azonos intenzitással és megszakítás nélkül zajlanak, négyféle minimális és négyféle maximális kapcsolatot képes kezelni.) Az MPM-technikának és a jelenleg alkalmazott hálós tervezési módszertanoknak kétségtelen előnyei mellett azonban olyan hátrányai vannak, melyek további kutatásokat tesznek szükségessé.

A hálós tervezési gyakorlat az elmúlt évtizedekben jelentôsen változott, $\mathrm{s}$ ez a változás magyarázható a számítástechnika elterjedésével és fejlódésével, valamint a kutatási eredmények gyakorlatba történő ültetésének problémájával. A 60-as és 70-es évek mainframe gépei, illetve az azok használatához szükséges szakértelem a projekttervezést rendkívül költséges és lassú eljárássá tette, legalábbis a mai fogalmaink szerint. A gépek kezeléséhez szükséges matematikai és informatikai ismeretek miatt a projekttervezéssel összefüggó munka csak átlagosan 10\%-ban volt tényleges tervező-munka, a maradék $90 \%$ az adatbevitel és -kinyerés érdekében végzett matematikusi és informatikai jellegú feladat volt. A rendszerek a 60 -as években nem kezelték a projektnaptárakat, a 70-es években fejlesztett rendszerek már egy naptárt képesek voltak kezelni.

A személyi számítógépek elterjedésével kezdődött a projekttervezó eszközök széles körú térhódítása is, ma mintegy százmillió példányban található valamilyen projekttervezési eszköz személyi számítógépen. Ez szinte hihetetlen fejlődés, különösen, ha felidézzük, hogy az elsố, széles körben kapható ütemezố szoftver az MS Project 1.0 1990. április 30-án került a piacra. Az elsô ütemezó szoftverekre általában jellemző volt, hogy informatikailag instabilak voltak, s gyakran az időelemzô algoritmus is rosszul számolt, s igen sok „sebból vérzett”. Elmondhatjuk, hogy a 90-es évek teljes egészében gyakorlatilag az algoritmusok javítása, valamint a felhasználói felület barátságosabbá tételének jegyében teltek el. (A Gantt-diagram logikai kapcsolatainak ábrázolása pl. csak a MS Project 4.0 verziójában jelent meg 1994-ben.)

A személyi számítógép elterjedése egyben azt is eredményezte, hogy egyre több „dilettáns” kezdett projekttervezéssel foglalkozni, és az ütemterv tartalma helyett elótérbe került az ütemterv „attraktív” megjelenése.

A fentieket alátámasztó ijesztô - és a projektmenedzser-társadalom egy jelentôs részének felkészületlenségét is jól jelzó - példa, hogy az egyik kereskedelmileg igen sikeres és elterjedtnek mondható szoftver az esetek túlnyomó részében (mintegy 95\%-ban) elrontotta a tevékenységek késôii időpontjainak kiszámítását, így a kritikus út meghatározását. Ezt a hibát (majd egy évtizeden keresztül) 1998-ig sem a fejlesztôk, sem a felhasználók nem vették észre, amikor is a hiba kijavítása az 1998-ban kiadott új verzióban észrevétlenül megtörtént.

Az ezredforduló után elmondható, hogy a szoftverek az esetek jelentôs részében jól számolnak, megbízhatóan számolják a kritikus utat, az erőforrás-tervezési algoritmusok, azonban még mindig heurisztikus algoritmusok melyek az igényeket nem mindig tudják kielégíteni. Az MPM-modellen alapuló projekttervezó szoftverból számtalan létezik, például itt említhető meg a maximális kapcsolatok kezelésére is képes magyar fejlesztésú ProjectDirector tervezőrendszer.

$\mathrm{Az}$ informatikai megoldások egyre inkább segítik a felhasználót, a kezelói felületek barátságosabbak, csoportmunka-megoldásokat is támogatnak mind a tervezés, mind a monitoring során. Megjelentek a projektalapú vállalatok múködését támogató vállalati projektmenedzsment-rendszerek, melyek a projekt teljes életciklusát végigkísérik, azaz az elő́készítést, a tervezést, illetve a monitoring- és kontrollingfeladatok elvégzését is támogatják. Közös jellemzőjük e rendszereknek, hogy a projekttel kapcsolatos dokumentumokat, pl. szerződések, gazdasági bizonylatok, is kezelik, s kifinomult jogosultsági rendszer segítségével biztosítják az adatok bevitelének és hozzáférésének lehetôségét.

Kialakult a ,projekttervező" szakma, Magyarországon is egyre többen foglalkoznak csak projekttervezéssel a projektmenedzser alá beosztva. Magyarországon is jelentôs méretú, akár több ezer tevékenységet tartalmazó ütemtervek készülnek, pl. az autópályaprojektek követésére, s olyan rendszerek is léteznek, melyek egyszerre több száz projekt adataiból vállalati szintú eredményességi adatokat produkálnak a menedzsment számára. 
A hálós tervezés ötven éve, értékelhetố projekttervezési gyakorlat azonban csak mintegy 10-15 éve létezik, és az a másfél évtized olyan sokirányú és rengeteg változást hozott egyszerre a módszertanban, a számítástechnikai eszközökben és a szoftverekben egyszerre, hogy nehéz ezek hatását külön-külön, egymástól függetlenül értékelni. Bizonyos módszertani, illetve hálótechnikai problémák azonban léteznek, és ismertek a felhasználók, a fejlesztő́k és a kutatók előtt is.

Az egyik jelentôs hálótechnikai probléma, hogy az MPM hálómodelljének legalapvetốbb hipotézise komoly gondot okoz a tervezőnek. Ez a hipotézis azt mondja ki, hogy a tevékenység azonos intenzitással és megszakítás nélkül folyik, különben nem tekinthetô tevékenységnek. (A modellnek erre a feltevésre azért van szüksége, mert csak e feltételezés teljesülése esetén lehet használni a logikai kapcsolatokat.) Ez a hipotézis azonban a gyakorlatban soha nem teljesül, s elmondható, hogy a rendelkezésre álló négy logikai összefüggés (maximális kapcsolatok alkalmazása esetén nyolcféle logikai összefüggés) nem megfeleló a tevékenységek közötti sokrétú összefüggés modellezésére.

A módszertani problémák közül a legkomolyabbnak az látszik, hogy nincs olyan viszonylag gyors és hatásos módszertan, mely segítségével a tervezó korrektül fel tudja tárni a projekt belsố logikai összefüggéseit. Ez különösen akkor igaz, ha egy terv összefüggéseinek meghatározásában többféle szakértelemre van szükség, azaz a tervezónek több szakemberrel kell együttmúködnie a tervezés során. A megfelelő módszertan hiánya oda vezet, hogy a tervek hiányosak, a logikai összefüggések töredékét tartalmazzák, ami rossz megvalósítási idốpontokat eredményez, és a háló aktualizálásához szükséges időigény összemérhetố lesz a tervezéshez szükséges időigénnyel. (Ne feledjük, hogy a hálós technikák elő́nye a hagyományos technikákkal szemben, hogy képesek megórizni a logikai összefüggéseket, ami így könnyúvé teszi az aktualizálást, de mi az egésznek a haszna, ha nem vagyunk képesek azokat helyesen meghatározni?) Jelenleg egy jó terv megalkotása olyan feladat, mint hurkapálcikákból megépíteni az Eiffel-tornyot. Nem tudhatjuk, hogy hány pálcika maradt ki a toronyból, s azoknak mi lett volna a szerepük, ha a terhelés megváltozik.

A fent felsorolt problémák néhány éve fogalmazódtak meg a tervezók azon csoportjában, akik folyamatosan nagy projektek tervezésén és aktualizálásán dolgoztak, azonban a rendszerek fejlesztésével foglalkozó kutatók már foglalkoznak a problémákkal. A probléma azonban nem informatikai, hanem módszertani és elméleti, így gyors megoldás nem látszik a láthatáron.
Az MPM-modell problémáját (alaphipotézis tarthatatlansága) többféleképpen is meg lehet oldani, s ebben az irányban már születtek elméleti megoldások. E megoldások közül az látszik alkalmazhatónak, hogy a tevékenységet megfelelő számú, kis altevékenységre kell osztani (egészen addig, amíg a hipotézis már gyakorlati szempontból teljesítettnek tekinthetô), s így a tevékenység bármelyik szakaszára megfogalmazható logikai összefüggés egy másik tevékenység bármelyik részével kapcsolatban. A probléma informatikailag kezelhetô, de olyan módszertani megoldás nem áll rendelkezésre, melyet a tervezók egyszerúen alkalmazni tudnának.

A kutatások egyik iránya az olyan tudásbázisok kifejlesztése, melyekben bizonyos tipizált ütemtervek felhasználásával és azok módosításával teszik lehetôvé a projektlogika minél teljesebb feltárását. Ilyen kezdeményezések már ma is vannak, jelentős segítséget egyelôre nem jelentenek.

Ennél lényegesen bonyolultabbak és idóigényesebbek, de alkalmazhatóság szempontjából többet ígérnek azok a kutatások, melyek önmagukat tanító rendszerek (mesterséges intelligencia) alkalmazásával önállóan képesek egy-egy ütemterv logikai összefüggéseinek feltárására és a rendszerben megtalálható, illetve újonnan beadott szabályok alapján az ütemterv kialakítására. A már mintegy két évtizede ismert neurális hálózatok, s egyéb más kutatási eredmények is hozzájárulhatnak a probléma megoldásához. A jövő́t azonban nehéz megjósolni, s innentôl kezdve e dolgozat már csak a szerzó személyes véleményét tükrözi, ezért indokolt az egyes szám elsố személy használata. Véleményem szerint a közeljövő változásai informatikai oldalról várhatók, s a módszertani változásokat is az informatika fogja indukálni.

Ma már nemcsak a fejlesztő́k asztalán léteznek olyan rendszerek, melyek egy létesítmény idôbeli megvalósulását négydimenziós (negyedik dimenzió az idô) filmen teszik követhetôvé. Ez a fajta vizualitás nagy segítséget jelent a tervezóknek a tervezési hibák kiküszöbölésében, a logikai összefüggések teljesebbé tételében. Jelenleg ezek az eszközök nehézkesek, „élesben” történô tervezésre nem alkalmasak (a tevékenység és a kirajzolásra kerülő elem összerendelése nem jól megoldott), de előretörésük várható az elkövetkezó évtizedben.

A távolabbi jövő véleményem szerint a nem MPMtechnikán alapuló szakértői rendszereké, de ennek bekövetkeztét ma még nem lehet megmondani.

Egy biztos: Az elóbb említett szakértői rendszerek megszületésével kezdôdik a projekttervezés legújabb kora. 


\section{Lábjegyzet}

${ }^{1}$ Az ELM Menedzsment Kft. engedélyével Project Director szoftver használatával

${ }^{2}$ Az ELM Menedzsment Kft. engedélyével, Project Director szoftver használatával

\section{Felhasznált irodalom}

Arisawa, S. - Elmagrabhy, S.E. (1972): Optimal Time-Cost Trade-OPffs in GER networks. Management Scienece, July, Vol. 18, No. 11. pp. 589-599

Adamiecki, K. (1931): Harmonygraph Przeglad Organizaciji. Polish Journal on Organizational

Bonnal, P. - Gourc, D. - Hameri, A. - Lacoste, G. (1988): A Linear-Discrete Model for the Resource-constrained project Scheduling Problem. Construction management and Economics, Volume, 23, No. 8, pp. 797-814.

Eisner, H. (1962): A Generalized Network Approach to the Planning and Scheduling of a Research Project. Opearions research, Vol. 10, No. 1, pp. 115-125.

Elmagrabhy, S.E. (1964): An Algebra for the Analysis of generalized Activity Networks. Management Science, vol. 10, No. 3, pp. 494-514

Elmagrabhy, S.E. (1977): Activity networks: Project Planning and Control by Network Models. John Wiley $\&$ Sons, New York

Fondahl, J.W. (1st Ed. 1961, 2nd ed, 1962): A Non-Computer Approach to the Critica IPath Method for the Construction Industry, Department of Civil Engineering, Stanford University

Freeman, R.J. (1960): A Generalized PERT, Operations research, Vol. 8, No. 2, p. 28. Fulkerson, R.(1961): A Network Flow Computation for Preject Cost Curves. Management Science, Vol. 7, No. 2, January, pp. 167-178

Gantt, H.L. (1903): A Graphical Daily Balance in Manufacture. Transactions of the American Society of Mechanical Engineers, Volume XXIV, pp. 1322-1336

Gantt, H.L. (1919): Organizing for Work. Harcourt, Brace and Howe, New York

Hajdu, M. (1997): Network Scheduling Techniques for Construction Project Management. Kluwer Acedemic Publisher

Hajdu M. (1993): A költségtervezési feladat megoldása változó függőségi kapcsolatokat tartalmazó tevékenység csomópontú tervütemhálón. Egyetemi doktori értekezés, BME

Hindelang, T.J. - Muth, J.F. (1979): ADynamic Programming Algorithm for Decision CPM Networks. Operations Research, Vol. 27, No. 2, pp. 225-241

IBM (1964): Users Manual for IBM 1440 Project Control System (PCS)
Kelley, J.E. Jr. - Walker, M.R. (1989): The Origins of CPM, a Personal History. pmNetwork, Vol. III, No. 2, Feb.

Kelley, J.E. Jr. - Walker, M. R. (1961): Critical Path Planning and Scheduling: Mathematical Basis. Operations Research, Vol. 9, No. 3, pp. 296-320

Kelley, J.E. Jr. - Walker, M.R. (1959): Critical Path Planning and Scheduling. Proceedings of the Eastern Joint Computer Conference, pp. 160-173

Klafszky E. (1969): Hálózati folyamok. Bolyai János Matematikai Társulat, pp. 201-216

Malcolm, D.G. - Roseboom, J.H. - Clarck, C.E. - Fazar, W. (1959): Applications of a Technique for Research and Development Program Evaulation. Operations Research, Vol. 7, No. 5, pp. 646-669

Mályusz E. (1984): Zsigmond király uralma Magyarországon. Gondolat, Budapest

Mályusz L. (2004): A költségtervezési „time-cost trade-off” feladat általánosítása és megoldása. Alkalmazott Matematikai Lapok, Vol. 21, pp 1-23

Meyer, L. W. - Shaffer, L. R. (1963): Extensions of the Critical Path Method Through the Application of Integer Programming. Technical Report, Dept. of Civil Engineering, University of Illinois

Urbana Ill. Polman, N. (1994): The Polaris: A Revolutionary Missile System and Concept. Colloquium on Contemporary History, January 12, Naval Historical Center, Department of the Navy

Pritsker, A.A.B. - Happ, W.W. (1966): GERT Graphical Evaulation and Review Technique. Part I. Fundamentals. Journal of Industrial Engineering, Vol. 17, No. 5, pp. 267-274

Pritsker, A. A. B. - Whitehouse, G.E. (1966): GERT Graphical Evaulation and Review Technique. Part II. Applications. Journal of Industrial Engineering, Vol. 17, No. 5, pp. 293-301

Pritsker, A.A.B. (1974): The Precedence GERT User Manual. Pristker \& Associates Inc. Lafayette, IN

Roy, B. (1959): Théorie des graphes: Contribution de la théorie des graphes á l'étude de certains problémes linéaries Comptes rendus des Séances de l'Académie des Sciences, séence du Avril, pp. 2437-2449

Roy, B. (1962): Graphes et ordonnancements. Revue Francaise de Recherche Operationelle, pp. 323-333

Smith, B.C. - Hawass, Z. (2006): How The Great Pyramid Was Built. 2nd ed. Collins. London

Sun Tzu (1910): The Art of War. Department Of Oriental Printed Books, The British Museum Ancient

Weaver, P. (2006): A Brief History of Scheduling. Konferencia-előadás myPrimavera06. ápr. 4-6. Canberra

Cikk beérkezett: 2007. 3. hó

Lektori vélemény alapján átdolgozva: 2007. 5. hó 